\title{
Detection of Francisella tularensis by the polymerase chain reaction
}

\author{
ZHAI JUNHUI, YANG RUIFU, LU JIANCHUN, ZHANG SONGLE, CHEN MEILING, CHE FENGXIANG \\ and CUI HONG
}

Institute of Microbiology and Epidemiology, 20 Dongdajie, Fengtai District, Beijing 100071, PR China

\begin{abstract}
Francisella tularensis is the causative agent of tularaemia. Effective antibiotic treatment of tularaemia is now available, but the early diagnosis of tularaemia remains a problem. Four primers (three pairs) were designed to detect $F$. tularensis by the polymerase chain reaction (PCR), based on the previously published nucleotide sequence of T-cell epitopes of a $F$. tularensis membrane protein. Amplification of purified $F$. tularensis chromosomal DNA with the three pairs of primers resulted in three different products with sizes consistent with those predicted from sequence data (211 bp, $347 \mathrm{bp}$ and $568 \mathrm{bp}$ ). The specificity of the PCR was confirmed as no amplification was detected with a range of other bacteria. The sensitivity of the PCR was determined with limiting dilution PCR and viable counts. The preliminary application of the PCR to the detection of $F$. tularensis in aerosols and experimentally infected mice was investigated. Comparison of the results with those from traditional culture indicated that PCR was more sensitive. The animal challenge test showed that, $24 \mathrm{~h}$ after inoculation with $15 \mathrm{cfu}$ of $\boldsymbol{F}$. tularensis, $38(82.6 \%)$ of 46 blood samples were positive by PCR, whereas only $22(47.8 \%)$ were positive by culture. The results showed that PCR is a helpful tool for the detection of $F$. tularensis in blood, liver and spleen which should enable the rapid confirmation of clinical diagnoses of tularaemia.
\end{abstract}

\section{Introduction}

Tularaemia is a zoonotic bacterial disease that occurs endemically between $30^{\circ}$ and $71^{\circ}$ north latitude [1]. The causative agent, Francisella tularensis, can be divided into two main types [2]. F. tularensis biovar tularensis (Jellison type A) has been found so far only in North America, whereas $F$. tularensis biovar palaearctica (Jellison type B) occurs mainly in Asia and Europe and to a minor extent in North America. Type $A$ is associated with ticks and rabbits and is highly virulent in man, whereas type $B$ is found in mosquitoes and rodents and is less virulent for man.

Current diagnosis of tularaemia is usually performed by detecting specific antibody to $F$. tularensis by enzyme-linked immunosorbent assay or agglutination $[3,4]$. The antibody response to $F$. tularensis is highly specific, but in-vitro cross-reactions have been reported with Brucella spp. [5-9], Proteus vulgaris OX19 [10,11] and Yersinia spp. [12]. Although $F$.

Received 25 Aug. 1995; revised version accepted 19 March 1996.

Corresponding author: Dr Z. Junhui. tularensis can be isolated from blood [13, 14], diagnosis by this method is notoriously unreliable. In a recent study [14] in the southwest central USA, bacteria were isolated from only $13.2 \%$ of serologically confirmed cases. Thus, it is important to develop a sensitive detection system for the organism.

As few as 25 organisms of $F$ tularensis biovar tularensis given by aerosol are sufficient to induce tularaemia in man [3]. Non-immune laboratory employees who work routinely with this biovar can eventually acquire the disease [3]. The majority of experiments can be performed with $F$. tularensis live vaccine strain (LVS) (Jellison type $B$ ), with riskier experiments on wild-type strains kept to a minimum. The present studies employed two $F$. tularensis strains: the less virulent $F$. tularensis strain 410062 (Jellison type B) was chosen for studies of aerosolised bacteria because of the hazardous nature of $F$. tularensis biovar tularensis aerosols, and the highly virulent $F$. tularensis strain 410101 (Jellison type A) was used to challenge Shanghai mice.

The polymerase chain reaction (PCR) has been applied widely in molecular biology, genetics and 
medical microbiology since its development in 1985 [15] and numerous studies have shown that it is a powerful tool for the detection of specific nucleic acids. The aim of the present study was to develop a PCR-based assay for the sensitive detection of $F$. tularensis based on four primers (three pairs) designed from previously published nucleotide sequence of $\mathrm{T}$ cell epitopes of a $F$. tularensis membrane protein [16].

\section{Materials and methods}

\section{Chemicals and materials}

All chemicals were of the highest grade commercially available in China. Taq DNA polymerase and restriction endonucleases were purchased from Sino-American Biotechnology Company, Beijing.

\section{Bacteria, media and growth conditions}

The bacterial strains used in this study are listed in Table 1. F. tularensis strains 410062 and 410101 were kindly provided by the national reference laboratory for $F$ tularensis, Beijing. Other strains were purchased from the Institute of Microbiology, Academia Sinica, Beijing. All bacterial strains were grown at $37^{\circ} \mathrm{C}$ on agar supplemented with sheep blood 10\% (Institute of Microbiology and Epidemiology, Beijing) overnight except for F tularensis which was cultured on Francis Medium: Hottinges powder $1.5 \mathrm{~g} / \mathrm{L}$, glucose $10 \mathrm{~g} / \mathrm{L}$, $\mathrm{NaCl} 5 \mathrm{~g} / \mathrm{L}$, L-cysteine $1 \mathrm{~g} / \mathrm{L}$, agar $1.5 \%$, defibrinated rabbit blood 5\%, $\mathrm{pH} 7.3-7.4$ for 4 days.

\section{Preparation of PCR templates}

Colonies (c. $10^{8}-10^{9} \mathrm{cfu}$ ) were suspended in $10 \mathrm{mM}$ Tris- $\mathrm{HCl}(\mathrm{pH} 8.0)$ and SDS was added to $5 \% \mathrm{w} / \mathrm{v}$. DNA was then extracted with phenol-chloroform and precipitated with ethanol. DNA was finally dissolved in distilled water and used as template for the PCR reaction. In addition to the purified DNA, crude extracts of $F$. tularensis were prepared. One colony of $F$ tularensis in $500 \mu \mathrm{l}$ of phosphate-buffered saline (PBS) was boiled for $10 \mathrm{~min}$ and centrifuged at $2500 \mathrm{~g}$ for $5 \mathrm{~min}$; the supernate was then used as the target for PCR amplification.

\section{PCR of purified DNA and bacterial suspension}

Primers for PCR were designed from a previously published sequence of a T-cell epitope of a $F$. tularensis membrane protein [16]. Four primers $(\mathrm{P} 1-\mathrm{P} 4)$ were designed for use in three combinations (P1-P2, P2-P3 and $\mathrm{P} 1-\mathrm{P} 4)$ to amplify three different length of DNA fragments. The sequences of the primers were as follows: 5' TGG CGA GTG ATA CTG CTT G 3' (primer P1); 5' TAG GAT CCC ATT AGC TGT CCA CTT ACC 3' (P2); 5' GGA ATT CGT TAG GTG GCT CTG ATG AT $3^{\prime}(\mathrm{P} 3)$ and $5^{\prime}$ CGC TAA ACC TGC GAT TGA T 3' (P4).

The PCR reaction mix contained $10 \mathrm{mM}$ Tris- $\mathrm{HCl}(\mathrm{pH}$ 8.4); $50 \mathrm{mM} \mathrm{KCl} ; 1.5 \mathrm{mM} \mathrm{MgCl}_{2}$; gelatin $0.01 \%$; Triton X-100 0.1\%; Tween $200.01 \%$; $50 \mu \mathrm{M}$ each of dCTP, dGTP, dTTP, dATP; 100 pM of each primer and $1 \mathrm{U}$ of Taq polymerase. Amplification was performed in a Perkin Elmer DNA Thermal Cycler in 50- $\mu$ l volumes under the following conditions: pre-denaturation for $10 \mathrm{~min}$ at $97^{\circ} \mathrm{C}$, followed by the addition of $1 \mathrm{U} \mathrm{Taq}$ polymerase at $75^{\circ} \mathrm{C}$, then 35 cycles consisting of denaturation for $1 \mathrm{~min}$ at $94^{\circ} \mathrm{C}$, annealing for $1 \mathrm{~min}$ at $55^{\circ} \mathrm{C}$, extension for $1 \mathrm{~min}$ at $75^{\circ} \mathrm{C}$, followed by $10 \mathrm{~min}$ at $75^{\circ} \mathrm{C}$. PCR products were detected on ethidium bromide-stained agarose gels (Sigma, 1.5\%) in TBE. The identification of the PCR products was confirmed by restriction endonuclease analysis of the products and hybridisation studies.

\section{Restriction analysis of $P C R$ products}

The 211-bp, 347-bp and 568-bp products were digested with TaqI, HindIII, and TaqI respectively, under the conditions specified by the manufacturer.

\section{Nucleic acid hybridisation}

Nitrocellulose filters (Promega) were pretreated with $2 \times \mathrm{SSC}(1 \times \mathrm{SSC}$ is $150 \mathrm{~mm} \mathrm{NaCl}, 15 \mathrm{mM}$ citric acid $)$ for $2 \mathrm{~min}$, then incubated at $37^{\circ} \mathrm{C}$ for $2 \mathrm{~h}$. PCR products were denatured by boiling for $10 \mathrm{~min}$, then immersed in an ice-water mixture for $5 \mathrm{~min}$. Filters were spotted with these DNA samples $(3 \mu 1)$, then baked at $80^{\circ} \mathrm{C}$ for $2 \mathrm{~h}$. Filters were then pre-incubated in formamide $50 \%, 2 \times \mathrm{SSC}, 5 \times$ Denhardt's solution,

Table 1. Bacteria used in this study

\begin{tabular}{llll}
\hline Bacterial strains & PCR & Bacterial strains \\
\hline F. tularensis 410062 & + & Morganella morganii 430024 \\
F. tularensis 410101 & + & Yersinia pseudotuberculosis 410051 \\
Pseudomonas pseudomallei & - & Proteus vulgaris 430052 \\
Serratia marcescens & - & Proteus mirabilis 430011 \\
Brucella abortus & - & Hafnia alvei 45201 & - \\
Providencia stuartii 1.1209 & - & Yersinia pestis 410041 \\
Enterobacter cloacae & - & Escherichia coli 270011 \\
Klebsiella pneumoniae 1.1526 & - & Legionella pneumophila \\
Salmonella typhimurium 460691 & - & Shigella dysenteriae 480011 \\
Vibrio cholerae SM 6 & - & Yersinia enterocolitica 52302 \\
Bacillus anthracis & - & - \\
\hline
\end{tabular}


sheared and denatured salmon sperm DNA $1 \mu \mathrm{g} / \mathrm{ml}$, $20 \mathrm{mM}$ EDTA at $42^{\circ} \mathrm{C}$ for $4 \mathrm{~h}$. Hybridisation was performed in formamide $50 \%, 2 \times \mathrm{SSC}, 5 \times$ Denhardt's solution, sheared and denatured salmon sperm DNA $1 \mu \mathrm{g} / \mathrm{ml}$, sodium sulphate $2.5 \%$, biotin-labelled probe $100 \mathrm{ng} / \mathrm{ml}$. The probe was synthesised with primers P2 and P3 by the PCR method above, with biotin-11dUTP replacing $25 \%$ of dTTP. Filters were washed twice with $2 \times \mathrm{SSC}$, SDS $0.1 \%$ and twice with $0.1 \times \mathrm{SSC}$, SDS $0.1 \%$ each for $5 \mathrm{~min}$ at room temperature. Hybridisation was detected with the APVisualization Kit (Beijing Medical University) according to the manufacturer's instructions. Because the 568bp sequence and pBR322 DNA contain the 347-bp sequence, they should both hybridise with the 347-bp biotin-labelled probe.

\section{Limiting dilution $P C R$}

The sensitivity of the PCR was determined by limiting dilution PCR. F. tularensis 410062 colonies were harvested in PBS and then diluted in 10-fold steps to $10^{8}$. The number of organisms in $100 \mu \mathrm{l}$ of each dilution was determined by surface agar plate viable counts and $1 \mu \mathrm{l}$ of each dilution was subjected to PCR. Comparison of the two results enabled the sensitivity of the PCR to be determined.

\section{Detection of $F$. tularensis in aerosols}

A stainless steel chamber, with an interior volume of $500 \mathrm{~L}$, was used for the aerosolisation experiments. A built-in rotary drum with a speed of $4 \mathrm{rpm}$ was installed to maintain the stability of aerosols. Two bacterial concentrations were prepared for aerosolisation by diluting stock cultures with PBS containing bovine serum albumen (BSA) $0.01 \%$. Aerosols containing $F$. tularensis 410062 (attenuated strain, not harmful to man) were generated with a TK-2 nebuliser (Factory of Academy of Military Medical Sciences, Beijing) at a pressure of $127.4 \mathrm{KPa}$ and flow rate of $8 \mathrm{~L} / \mathrm{min}$ for $5 \mathrm{~min}$. PBS was aerosolised for $2 \mathrm{~min}$ and sampled as a negative control before each trial. At each bacterial concentration, organisms were sampled with AGI-10 impingers (containing $10 \mathrm{ml}$ of PBS, BSA $0.01 \%$, $50 \mu \mathrm{l}$ of olive oil) at a flow rate of $8 \mathrm{~L} / \mathrm{min}$ for $2 \mathrm{~min}$ at $0,10,20,40$ and $80 \mathrm{~min}$ after aerosolisation. The aerosolisation experiments were performed twice. Resulting samples were diluted in 10-fold steps to $10^{8}$ and the bacterial concentration was estimated by surface viable counts and PCR.

\section{Detection of F. tularensis in experimentally infected mice}

Specific-pathogen-free Shanghai mice (Experimental Animal Centre, Academy of Military Medical Sciences, Beijing) were inoculated intraperitoneally with $c .15$ (group 1) and 1.5 (group 2) cfu of F. tularensis strain 410101. Mice given the same volume of $\mathrm{NaCl} 0.9 \%$ solution were used as negative controls. Each day after injection, one mouse in each group was killed and blood, liver and spleen were sampled. Blood was subjected to PCR directly. Liver and spleen were homogenised with a glass tissue grinder, then treated with phenol-chloroform and DNA was precipitated with ethanol. DNA was finally dissolved in $100 \mu \mathrm{l}$ of distilled water (equivalent to the volume of the original sample). All these experiments were carried out in a level 3 biosafety laboratory of the Institute of Microbiology and Epidemiology, Beijing.

\section{Results}

Specificity and sensitivity of PCR assay

Eighteen different types of bacteria genetically unrelated to $F$. tularensis were tested in this assay; all organisms other than $F$. tularensis gave negative results by PCR (Table 1). Sensitivity was determined by limiting dilution PCR. A PCR product could be detected from samples containing $1 \mathrm{cfu}$ of $F$. tularensis/ $\mu 1$.

\section{PCR of purified DNA and crude extracts}

With primer pairs P1-P2, P2-P3 and P1-P4, PCR of purified DNA resulted in 568-bp, 347-bp and 211-bp products, respectively (Fig. 1), consistent with previously published sequence data [16]. PCR amplification from crude extracts of $F$ tularensis was also investigated with primer pair $\mathrm{P} 1-\mathrm{P} 2$. No significant difference was observed between the PCR results with bacterial suspension and purified chromosomal DNA.

\section{Identification of PCR products}

Restriction endonuclease digestion of the 211-bp, 347bp and 568-bp PCR products with Taq I, HindIII and Taq I, respectively, produced fragments consistent with the sizes predicted from the published sequence [16].

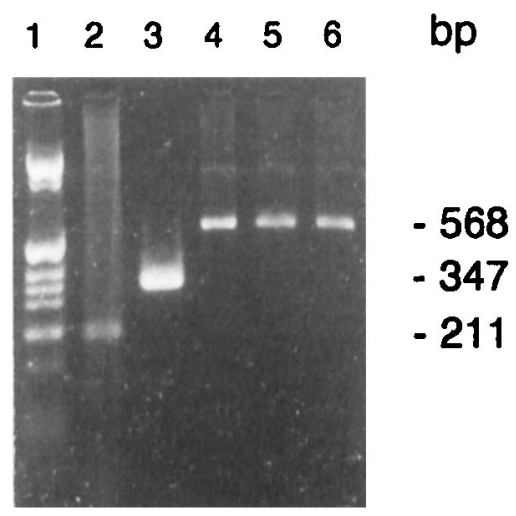

Fig. 1. PCR of purified DNA and bacteria suspension: Lane 1, pBR322 HinfI marker; 2, PCR of purified DNA with primer pair $\mathrm{P} 1-\mathrm{P} 4 ; 3, \mathrm{PCR}$ of purified DNA with $\mathrm{P} 2-\mathrm{P} 3 ; 4$, PCR of purified DNA with P1-P2; 5, PCR of strain 410101 suspension with $\mathrm{P} 1-\mathrm{P} 2 ; 6$, PCR of strain 410062 with P1-P2. 
The 347- and 568-bp products (3-300 ng) hybridised with the $347-$ bp biotin-labelled probe (Fig. 2).

\section{PCR of aerosol samples}

F. tularensis was detected by both culture and PCR (Table 2). The concentration of organisms in the aerosol samples was estimated by limiting dilution PCR (Table 2). For example, when $10^{5}$ dilution was PCR negative and $10^{4}$ was PCR positive (for $1 \mu \mathrm{l}$ of sample), the concentration of organisms could be approximately deduced as follows: 1 (i.e. at least one copy of bacterial genome detected) $\times 1000 \times 10^{4}=10^{7}$ genomes. PCR was approximately 10 times more sensitive than culture (Table 2).

\section{$P C R$ of experimentally infected mice}

Two mice died 6 days and 7 days after inoculation with $15 \mathrm{cfu}$ of $F$. tularensis, while one mouse died 7 days after inoculation with $1.5 \mathrm{cfu}$ of $F$. tularensis.

In total, 46 samples were investigated (Table 3), 38 $(82.6 \%)$ of which were PCR positive, whereas culture was positive for $22(47.8 \%)$. PCR of blood was positive $24 \mathrm{~h}$ after inoculation with $15 \mathrm{cfu}$ of $F$.

\begin{tabular}{|c|c|c|}
\hline 1 & 2 & 3 \\
\hline 4 & 5 & 6 \\
\hline 7 & 8 & 9 \\
\hline
\end{tabular}

Fig. 2. Nucleic acid hybridisation with biotin labelled probe: (1) 347-bp product, $300 \mathrm{ng}$; (2) 347-bp product, $30 \mathrm{ng}$; (3) 347-bp product, $3 \mathrm{ng}$; (4) No. 7 pBR322 DNA, $600 \mathrm{ng}$; (5) No. 16 pBR322 DNA, $600 \mathrm{ng}$; (6) 211-bp negative control, $300 \mathrm{ng}$; (7) 568-bp product, $300 \mathrm{ng}$; (8) 568-bp product, $300 \mathrm{ng}$; (9) 568 -bp product, $300 \mathrm{ng}$.

Table 2. Detection of $F$. tularensis in aerosols

\begin{tabular}{|c|c|c|c|c|c|c|c|c|c|c|}
\hline \multirow{2}{*}{$\begin{array}{l}\text { Time after } \\
\text { aerosolisation } \\
(\mathrm{min})\end{array}$} & \multirow{2}{*}{$\begin{array}{c}\text { Viable } \\
\text { count } \\
(\mathrm{cfu} / \mathrm{ml})^{*}\end{array}$} & \multicolumn{9}{|c|}{ PCR result at dilution } \\
\hline & & $10^{0}$ & $10^{1}$ & $10^{2}$ & $10^{3}$ & $10^{4}$ & $10^{5}$ & $10^{6}$ & $10^{7}$ & $10^{8}$ \\
\hline 0 & $6.0 \times 10^{6}$ & + & + & + & + & + & - & - & $\ldots$ & $\cdots$ \\
\hline 10 & $1.4 \times 10^{6}$ & + & + & + & + & $-1+^{\dagger}$ & - & $\ldots$ & $\ldots$ & $\ldots$ \\
\hline 20 & $4.5 \times 10^{5}$ & + & + & + & + & - & $\cdots$ & $\cdots$ & $\cdots$ & $\cdots$ \\
\hline 40 & $4.4 \times 10^{4}$ & + & + & + & + & - & $\ldots$ & $\ldots$ & $\ldots$ & $\ldots$ \\
\hline 80 & $9.3 \times 10^{3}$ & + & + & + & - & $\cdots$ & $\cdots$ & $\cdots$ & $\cdots$ & $\cdots$ \\
\hline Control (PBS) & 0 & - & $\cdots$ & $\cdots$ & $\cdots$ & $\cdots$ & $\ldots$ & $\cdots$ & $\cdots$ & $\ldots$ \\
\hline Storage suspension & $1.2 \times 10^{9}$ & + & + & + & + & + & + & + & $-1++^{\dagger}$ & - \\
\hline
\end{tabular}

${ }^{*}$ The mean value of two separate aerosolisation experiments.

${ }^{\dagger}$ Discrepant results in the two trials; other results were concordant.

Table 3. Detection of $F$. tularensis in mice

\begin{tabular}{|c|c|c|c|c|c|c|}
\hline \multirow{3}{*}{$\begin{array}{l}\text { Days } \\
\text { after } \\
\text { injection }\end{array}$} & \multicolumn{6}{|c|}{ Culture and PCR results with } \\
\hline & \multicolumn{3}{|c|}{ Group $1(15 \mathrm{cfu})$} & \multicolumn{3}{|c|}{ Group 2 ( $1.5 \mathrm{cfu})$} \\
\hline & Blood & Liver & Spleen & Blood & Liver & Spleen \\
\hline 1 & $-1+^{*}$ & $-1+$ & $-1+$ & - & - & - \\
\hline 2 & + & $-1+$ & + & - & $-1+$ & $-1+$ \\
\hline 3 & + & $-1+$ & + & + & $-1+$ & + \\
\hline 4 & + & + & + & + & $-1+$ & + \\
\hline 5 & + & - & $-1+$ & + & - & $-1+$ \\
\hline 6 & + & $-1+$ & + & - & $-1+$ & + \\
\hline 7 & + & $-1+$ & + & - & $-1+$ & $-1+$ \\
\hline dead & $\cdots$ & + & + & $\cdots$ & $-1+$ & + \\
\hline
\end{tabular}

*For discrepant results, first symbol represents culture result and second represents PCR result. Other results were concordant. - , negative results, + , positive result, $\cdots$, blood not available from dead animals. 
tularensis in all cases. F. tularensis was detected in samples from mice inoculated with $1.5 \mathrm{cfu}$ as early as $48 \mathrm{~h}$ after injection (Table 3). Samples from control mice were consistently negative for $F$. tularensis by culture and PCR.

\section{Discussion}

Little is known about the genetics and molecular biology of $F$. tularensis. The first study on nucleotide sequence analysis of $F$. tularensis was conducted by Sjostedt et al. in 1990 [16]; this enabled us and other workers to design primers for PCR [17]. Because the two biovars (Jellison types $\mathrm{A}$ and $\mathrm{B}$ ) of $F$. tularensis both share the TUL4 antigen, PCR of the two strains gave the same result [17]. Primers based on the above sequence were designed to distinguish strains at the genus and species levels.

Because human tularaemia can be treated effectively with antibiotics [18], methods which detect $F$. tularensis early in the disease course may facilitate effective treatment [4]. Laboratory diagnosis of tularaemia is usually by detecting antibodies against F. tularensis $[3,4]$ with, for example, the bacterial micro-agglutination test $[19,20]$, which may be performed 8-10 days after initial clinical symptoms of tularaemia appear, or enzyme-linked immunosorbent assay (ELISA) [19-22], which may show classspecific antibodies slightly earlier after the onset of illness than agglutination assays. Both methods are too slow to be clinically useful because of the rapid progress of tularaemia. Moreover, the specificity of agglutination and ELISA is often uncertain because cross-reactions have been found with Brucella spp. [5-9], Proteus vulgaris OX19 [10,11] and Yersinia spp. [12]. The present study developed a PCR-based assay to detect $F$. tularensis in samples of aerosols and laboratory-infected mice and showed that this technique provides a rapid, specific and sensitive method for the detection of $F$. tularensis.

Detection and quantification of airborne $F$ tularensis was achieved by culture and limiting dilution PCR. Viable counts determined by culture were found to underestimate the aerosolised bacterial concentration when compared with the PCR method. The underestimation of $F$. tularensis by culture may be due to the slow growth of $F$. tularensis, the failure of some bacteria to grow on Francis medium or death of organisms during the aerosolisation experiments. Although the non-culturable organisms would not be detected by viable counts, they would still be good targets for PCR. This underestimation is clinically significant because a fraction of bacteria in the aerosols may be viable, yet non-culturable. In the case of $F$ tularensis, viability, but not necessarily culturability, is the measure of infectious potential. Underestimation of viable $F$ tularensis and other bacterial pathogens (such as Legionella pneumophila [23]) can have serious health consequences, because the infectious dose of a pathogenic organism can be very small. This underscores the need for developing sensitive analytical techniques, such as PCR, that can be used in addition to culture methods.

F. tularensis is described as a facultative intracellular parasite, although direct proof of intracellular replication of $F$ tularensis in mononuclear phagocytes is scarce [3]. An animal challenge test [24] showed that when mice were inoculated with $F$. tularensis LVS intravenously, and killed $15 \mathrm{~min}$ after injection, $69.9 \pm 5.4 \%$ of injected bacteria were recovered from blood, $4.8 \pm 0.3 \%$ from liver and $8.6 \pm 0.7 \%$ from spleen. The results of the present study showed that organisms were isolated from the blood of nine $(64.3 \%)$ of 14 mice, two (12.5\%) of 16 livers and ten $(62.5 \%)$ of 16 spleen samples. It is usually thought that the lymph organs (especially liver and spleen) of mice infected with $F$. tularensis contain many bacteria and the reasons for low viable counts from liver cultures are not known. One possibility is the killer ability of liver, unlike spleen (which only concentrates organisms). Another possibility is that organisms may die during the sampling process. Furthermore, inhibitory substances may be released during homogenisation of tissue, hindering the growth of bacteria.

The present study showed that PCR of blood and spleen was positive $24 \mathrm{~h}$ after inoculation of mice with $15 \mathrm{cfu}$ of $F$ tularensis (group 1), whereas PCR of blood was positive $48 \mathrm{~h}$ after injection of $1.5 \mathrm{cfu}$ of organisms (group 2). It seems that the higher the inoculation dose used, the earlier the detection by PCR. The negative results by PCR may be due to low concentrations of bacteria, inadequate sample preparation, low efficiency of amplification or low resolution of agarose gel electrophoresis. The latter could be improved by Southern blotting and hybridisation.

In conclusion, the present study indicates that PCR can be used for rapid and specific identification of $F$. tularensis in aerosols and experimentally infected mice and, when compared with traditional culture or serology, PCR can be expected to be considerably more reliable and specific in clinical situations.

\section{References}

1. Hopla CE. The ecology of tularemia. Adv Vet Sci Comp Med 1974; 18: 25-53.

2. Olsufiev NG, Emelyanova OS, Dunayeva TN. Comparative study of strains of $B$. tularense. II. Evaluation of criteria of virulence of Bacterium tularense in the old and the new world and their taxonomy. $J$ Hyg Epidemiol Microbiol Immunol 1959; 3: $138-49$.

3. Tarnvik A. Nature of protective immunity to Francisella tularensis. Rev Infect Dis 1989; 11: 440-51.

4. Geisbert TW, Jahrling PB, Ezzel JW. Use of immunoelectron microscopy to demonstrate Francisella tularensis. $J$ Clin Microbiol 1993; 31: 1936-1939. 
5. Francis E, Evans AC. Agglutination, cross-agglutination, and agglutinin absorption in tularemia. Public Health Rep 1926; 41: $1273-1295$.

6. Ransmeier JC, Ewing CL. The agglutination reaction in tularemia. $J$ Infect Dis 1941; 69: 193-205.

7. Kadull PJ, Reames HR, Coriell LL, Foshay L. Studies on tularemia. V. Immunization of man. J Immunol 1950; 65: 425-435.

8. Saslaw S, Carlisle HN. Studies with tularemia vaccines in volunteers. IV. Brucella agglutinins in vaccinated and nonvaccinated volunteers challenged with Pasteurella tularensis. Am J Med Sci 1961; 242: 166-172.

9. Warring WB, Ruffin JS. A tick-borne epidemic of tularemia. $N$ Engl J Med 1946; 234: 137-140.

10. Snyder MJ. Immune response to Francisella. In: Rose NR, Friedman $\mathrm{H}$ (eds) Manual of clinical immunology. Washington, DC, American Society for Microbiology. 1986 377-378.

11. Koskela P, Herva E. Immunity against Francisella tularensis in north Finland. Scand J Infect Dis 1982; 14: 195-199.

12. Behan KA, Klein GC. Reduction of Brucella species and Francisella tularensis cross-reacting agglutinins by dithiothreitol. J Clin Microbiol 1982; 16: 756-757.

13. Provenza JM, Klotz SA, Penn RL. Isolation of Francisella tularensis from blood. J Clin Microbiol 1986; 24: 453-455.

14. Taylor JP, Istre GR. McChesney TC, Satalow FT, Parker RL, McFarland LM. Epidemiology characteristics of human tularemia in the southwest-central states, 1981-1987. Am J Epidemiol 1991; 133: 1032-1038.

15. Saiki RK, Scharf S, Faloona F et al. Enzymatic amplification of $\beta$-globin genomic sequence and restriction site analysis for diagnosis of sickle cell anemia. Science 1985; 230: $1350-1354$.
16. Sjöstedt A, Sandström G, Tarnvik A, Jaurin B. Nucelotide sequence and $\mathrm{T}$ cell epitopes of a membrane protein of Francisella tularensis. J Immunol 1990; 145: 311-317.

17. Long GW, Oprandy JJ, Nrayanan RB, Fortier AH, Porter KR Nacy CA. Detection of Francisella tularensis in blood by polymerase chain reaction. $J$ Clin Microbiol 1993; 31: $152-154$.

18. Overholt EL, Tigertt WD, Kadull PJ et al. An analysis of forty-two cases of laboratory-acquired tularemia. Treatment with broad spectrum antibiotics. Am J Med 1961; 30: $785-806$.

19. Bevanger L, Maeland JA, Naess AI. Agglutinins and antibodies to Francisella tularensis outer membrane antigens in the early diagnosis of disease during an outbreak of tularemia. $J$ Clin Microbiol 1988; 26: 433-437.

20. Syrjala H, Koskela P, Ripatti T, Salminen A, Herva E. Agglutination and ELISA methods in the diagnosis of tularemia in different clinical forms and severities of the disease. J Infect Dis 1986; 153: 142-145.

21. Bevanger L, Maeland JA, Naess AI. Competitive enzyme immunoassay for antibodies to a 43,000-molecular-weight Francisella tularensis outer membrane protein for the diagnosis of tularemia. J Clin Microbiol 1989; 27: 922-926.

22. Carlsson HE, Lindberg AA, Lindberg G, Hederstedt B, Karlsson KA, Agell BO. Enzyme-linked immunosorbent assay for immunological diagnosis of human tularemia. $J$ Clin Microbiol 1979; 10: 615-621.

23. Mukoda TJ, Todd LA, Sobsey MD. PCR and gene probes for detecting bioaerosols. J Aerosol Sci 1994; 25: 1523-1532.

24. Anthony LSD, Kongshavn PAL. Experimental murine tularemia caused by Francisella tularensis, live vaccine strain: a model of acquired cellular resistance. Microb Pathog 1987; 2: 3-14. 